\title{
Supporting Key Aspects of Practice in Making Mathematics Explicit in Science
}

\section{Lessons}

\begin{abstract}
STEM integration has often been recommended as a way to support students to develop $21^{\text {st }}$ Century skills needed to function in the complex modern world. In order for students to experience integration, however, their teachers need support in designing, developing and implementing integrated curricular instruction, which is often at odds with a very subject-focused educational system. This paper reports on the second year of a research study conducted with five secondary science and mathematics teachers, concerned with supporting them to teach explicitly the mathematics components within science lessons, mediated via technology. It outlines how the teachers collaborated with the support of science and mathematics education researchers within a community of practice, named a Teaching and Learning Network (TLN). The network was intended to promote and enhance teacher capacity for the interdisciplinary teaching of mathematics in science in the face of various contextual and other obstacles observed in the first year of the study. This study found that the opportunity to work in a Teaching and Learning Network supported the teachers' ownership of the design of the integrated learning unit, enhanced their content knowledge of the mathematics, their use of the data logging technology and their understanding of an inquiry based pedagogical approach. Participation in the TLN provided teachers with the mechanism to cross the boundaries of the subject disciplines, and thereby promoted change in their attitudes, professional knowledge and to some extent, practice.
\end{abstract}


Keywords: community of practice, cross-curricular, in-service teachers, interdisciplinary teaching, STEM integration

Integration of mathematics and science has a long and rich history within secondary education, and few would dispute that integration of these two closely related subjects should be encouraged within the secondary classroom (Berlin \& Lee, 2005; Frykholm \& Glasson, 2005). Recommendations for the integration of STEM subjects have been made by a number of professional mathematics and science subject associations and educational bodies, internationally, including in the framework document for the Next Generation Science Standards (NGSS) in the US (Czerniak \& Johnson, 2014; Furner \& Kumar, 2007; NGSS Lead States, 2013). However, the possibilities for integration of these or any subjects are threatened by a strong focus on student performance in subject-based examinations. In Ireland secondary teachers have traditionally been reluctant to implement integration because of the constraints imposed by highly-prescriptive curricula and by an educational culture focused on teaching to the test. The test in this case refers to discipline-focused mandated terminal examinations at the end of both lower and higher secondary education. However, on-going changes in the curricula for mathematics and science within Ireland have opened up a curricular space for teachers to make connections across these two closely related subjects. There is more focus on supporting students to see the utility and application of concepts and skills in real-life and also across subjects (NCCA, 2019). While this helps to align the Irish educational system with international curricular trends in cross-curricular approaches within secondary education (Hargreaves, Lieberman, Fullan, \& Hopkins, 2010), it also raises the question of how teachers can be supported to make the quite radical changes in practice necessary to successfully implement integrated approaches to their teaching of mathematics and science. 
This paper reports on the second year of a study undertaken in Ireland with five in-service science and mathematics teachers from three secondary schools. The focus of the study was to support the teachers' integration of science and mathematics in their lower secondary teaching, mediated via the use of data-logging technology. Outcomes of the first year of the study revealed a number of key aspects of practice that impacted upon the teachers' implementation of the integrated unit (Authors, 2016). In particular, for the purposes of this paper, it revealed that the participating secondary science and mathematics teachers needed considerably more support and encouragement to take ownership of their implementation of integrated lessons, in developing their facility with the data logging technology and its integration into their teaching, in taking a student-centred approach to implementing integration, in changing their beliefs and perceptions about integration, and in developing appropriate knowledge of the content of the mathematics in the integrated units. Working within the realities of the Irish educational context, with its strong subject-focus and lack of school support for integration (Gleeson, 2010; Authors, 2016), the research team responded to the outcomes from the first year of the study by changing the approach in a number of ways in the second year, in order to enhance teacher capacity. Table 1 shows the main differences between the design of Year 1 and Year 2 of the project. The main focus of Year 2 was to develop further the community of practice $(\mathrm{CoP})$ approach that had been initiated in a more muted fashion in Year 1. Year 2 concentrated on evolving this professional learning community, external to school structures, and composed of the five teachers and the researchers. Its purpose was to act as a vehicle to support and promote teacher change with respect to teacher attitudes, ownership and practice in regard to the integration of mathematics and science. Unlike Year 1, the teachers were centrally involved in designing the integrated unit in Year 2, within the context of the CoP, named a Teaching and Learning Network (TLN). The TLN approach was intended to provide the science and mathematics 
teachers with a safe environment within which they could experiment with this innovative interdisciplinary approach, where they received the encouragement of their peers, where they could pool complementary knowledge and skills of teaching mathematics and science, and most importantly, share ideas and problems with the team, something often unavailable within schools (Butler, Lauscher, Jarvis-Selinger, \& Beckingham, 2004). The TLN provided them with structured support with regard to inquiry-based learning, the use of the technology and specific mathematical concepts relevant to science. The decision was made, by the teachers and researchers, to focus on explicitly integrating mathematics into a science lesson unit. More broadly, participation in the TLN was the mechanism by which teachers could develop their boundary crossing competence, that is, their capacity to traverse the sociocultural and disciplinary boundaries between two different school subjects (Akkerman and Bakker, 2011; Hobbs, 2013).

This paper reports on the process of developing an integrated science and mathematics lesson unit within the TLN, and the extent to which this supported teachers to change their practice.

Table 1: Main differences between Year 1 and Year 2 of the project

\begin{tabular}{ll}
\hline Year 1 & Year 2 \\
\hline $\begin{array}{l}\text { Design of integrated lesson unit was } \\
\text { primarily researcher-led }\end{array}$ & $\begin{array}{l}\text { Design of integrated lesson unit was } \\
\text { primarily teacher-led }\end{array}$ \\
\hline $\begin{array}{l}\text { Meetings focused on researchers developing } \\
\text { teacher familiarity with the data logging }\end{array}$ & $\begin{array}{l}\text { Teacher Learning Network (TLN) meetings } \\
\text { were collaborative sessions between } \\
\text { technology, and with the integrated lesson } \\
\text { researchers and teachers, with targeted } \\
\text { professional development for supporting } \\
\text { teacher TPACK, understanding of trend } \\
\text { graphs and inquiry-based learning }\end{array}$ \\
\hline $\begin{array}{l}\text { Lesson unit involved moving from } \\
\text { mathematics class to science class and back } \\
\text { again }\end{array}$ & $\begin{array}{l}\text { Lesson unit focused on enhancing the } \\
\text { mathematics content within a learning unit } \\
\text { implemented in the science class }\end{array}$ \\
\hline
\end{tabular}


The research questions addressed by this study are: 1 . Does the establishment of a TLN enhance teacher attitudes and support their professional knowledge development with respect to integrated science and mathematics teaching and learning? 2. Does working in a TLN support teachers to change their practice from subject-specific focused teaching, to integrated teaching utilising an IBL approach?

In the following section the literature on teacher attitudes and perceptions with regard to integration of science and mathematics is outlined, followed by discussion of the literature on supporting teacher professional learning within a $\mathrm{CoP}$, and on boundary crossing between different CoPs. As the literature indicates, collaboration within a $\mathrm{CoP}$ can be a powerful vehicle for supporting teachers to make the journey from absorbing new ideas, to changing beliefs and attitudes, to transforming practice. This is true for any educational innovation, but particularly for the integration of two school subjects, where the need for curriculum stakeholders to collaborate in order to share expertise across subject boundaries is a prerequisite of successful integration.

\section{Challenges in Implementing an Integrated Curricula}

Integration of mathematics and science (and other subjects) can provide students with a coherent curriculum whereby concepts, processes and skills are connected across the various subjects (Howes, Kaneva, Swanson, \& Williams, 2013), bringing about more meaningful learning, and supporting student understanding and attitudes towards both subjects (Czerniak \& Johnson, 2014; Gresnigt, Taconis, van Keulen, Gravemeijer, \& Baartman, 2014; Venville, Sheffield, Rennie, \& Wallace, 2008). While integration of mathematics and science may be beneficial for student learning of both subjects (Burghardt, Lauckhardt, Kennedy, Hecht, \& McHugh, 2015; Judson \& Sawada, 2000; Roseno et al., 2015), it can be difficult for teachers to implement for a number of reasons. On a practical level, common reasons given by teachers for difficulties in enacting integration are lack of 
time and lack of resources (Czerniak \& Johnson, 2014; Offer \& Vasquez-Mireles, 2009). Most secondary teachers do not have many opportunities (planned and/or unplanned) to work with teachers in other subject disciplines in their day to day lives as borne out by the precursor study, where teachers found it difficult to find time for collaboration within school structures that made no provision for this and where they received little organisational support (Authors, 2016). This is compounded by systemic barriers such as the imposition of standards on teachers and performativity measures that assess discipline-focused concepts (Berlin \& White, 2012; Hargreaves, Earl, Moore, \& Manning, 2001). This has led to less frequent attempts to develop integrated science and mathematics curricula in more recent years (Berlin \& White, 2012; Czerniak \& Johnson, 2014).

There are few pre-service, and even fewer in-service, teacher education programmes where teachers get to experience integrated science and mathematics pedagogy courses (Berlin \& White, 2012; Furner \& Kumar, 2007). Additionally, teachers' subject content knowledge in the other discipline can be insufficient to integrate both subjects fully (Czerniak \& Johnson, 2014; Stinson, Harkness, Meyer, \& Stallworth, 2009). It has been found that one of the key aspects of practice that impacts on the implementation of an integrative approach to mathematics and science education is a lack of teacher knowledge of the 'other subject' (Authors, 2016). Teachers themselves have expressed concerns about their lack of knowledge of subjects in which they are not qualified, leading to a lack of confidence in teaching them (Lee, Chauvot, Vowell, Culpepper, \& Plankis, 2013; Authors, 2017). However, studies where teachers have had the opportunity to experience science and mathematics integration in professional development programmes have shown that this supported their development of deeper understanding of how to connect the disciplines (Baxter, Ruzicka, Beghetto, \& Livelybrooks, 2014). In Year 2 of this research the focus was on the development of a 
community of practice, the TLN, in which teachers and researchers could together explore how best to integrate mathematics and science.

\section{Supporting Integration Through Communities of Practice}

Lave and Wenger (1991) have argued that all learning is situated, whereby individuals learn in the context of communities of practice. Moreover, the literature suggests that it is unrealistic and undesirable to expect teachers to change their individual classroom practices, their values and thinking, on their own and against the norm. Change will not occur if the distributed and shared nature of knowledge is not addressed (Dori \& Herscovitz, 2005). There has been a shift in understanding of teachers as learners over the past 50 or so years, from a developmental to a professional learning model in which teachers are given more autonomy and responsibility for their development of professional knowledge (Loughran, 2014). Loughran (2014) notes that teacher development hinges on teacher learning, and learning is more valuable when supported through collaboration. Butler et al., (2004) state that collaborative models for teacher learning emphasise the importance of nurturing learning communities within which teachers try new ideas, reflect on outcomes, and co-construct knowledge about teaching and learning.

Collaborative inquiry in a community of practice may also be beneficial for teachers by providing opportunities for reflection not typically available to practicing teachers, and essential for making a meaningful shift in practice, while, working with others also has the potential to sustain momentum through inevitable challenges, generating energy and enthusiasm for implementing innovation (Butler et al., 2004). Participation in a learning community provides teachers with the opportunity to work together to develop shared meanings through questioning, clarification, negotiation, and consensus-building, resulting in the emergence of new ideas and understandings (Borko, Mayfield, Marion, Flexer, \& Cumbo, 1997), supporting risk-taking and the struggle needed to transform practice (Putnam \& 
Borko, 2000), and giving teachers a sense of control and ownership over their professional learning (Berry, Loughran, Smith, \& Lindsay, 2009) . Moreover, by their nature, CoPs present the opportunity for individuals to draw on the distributed expertise and knowledge of the group (Putnam \& Borko, 2000) - which is particularly important in the context of integration of two distinct subjects. CoPs can provide a safe environment where teachers can verbalise and share their learning processes and internal struggles (Akerson, Cullen, \& Hanson, 2009; Loughran, Smith, \& Berry, 2011), leading to enhanced teacher self-efficacy and better implementation of new methods (Lakshmanan, Heath, Perlmutter, \& Elder, 2011), more effective classroom learning, stronger professional confidence and improved teachers' capacity to respond to change (Hargreaves et al., 2001). Therefore, building a community of practice of teachers and researchers for the purposes of collaboration to develop and implement integration is more likely to have a lasting impact on teachers' practice. Importantly, working with teachers of other subjects in learning communities can help to overcome shortcomings in individual teacher knowledge of particular subjects, as well as structural barriers to integration in school settings (Frykholm \& Glasson, 2005; Hargreaves et al., 2001; Rennie, Venville, \& Wallace, 2012).

However, teachers of school subjects, and indeed researchers located in Higher Education, are already members of their own quite distinct communities of practice. Teachers' CoPs at second-level are defined by the subjects they teach and their professional identities are formed by their commitment to their subject-specific CoPs (Hobbs 2013). The analytical concept of boundary crossing between different communities of practice (Akkerman and Bakker, 2011; Kent et al., 2007; Nicolini et al., 2012) provides a framework for understanding the mechanisms by which practitioners interact across subject boundaries. Boundaries are here defined as sociocultural differences that effectively establish and define expertise and rights of participation within different domains of professional practice 
(Akkerman and Bakker, 2011). Boundaries between different communities of practice constitute an ambiguous and ill-defined space, but they also represent opportunities for creativity and learning. Boundary crossing entails the activities of individuals or groups to establish continuity in action or interaction across different practices (Akkerman and Bakker, 2011). This is often mediated via boundary objects, artefacts or processes that perform a bridging function between communities (Kent et al., 2007). Participation in a boundary crossing mechanism, the TLN in this case, can therefore provide professional learning opportunities that can lead to teacher subject identity expansion and their reconceptualisation of their practice (Hobbs, 2013).

In summary, while it is clear that teacher collaboration is essential to successfully create and implement integrated learning of science and mathematics, the conditions for such collaboration must be carefully nurtured and encouraged within a new community of practice that bridges pre-existing subject-specific CoPs. The TLN straddled the three schools and the research centre. Here teachers and researchers could build on their complementary skill sets to facilitate teacher capacity to integrate mathematics and science. This would include providing teachers with opportunities to develop further their understanding of the datalogging technology, the mathematical concepts required for the science, and in taking an inquiry-based pedagogical approach. Most importantly it was intended to provide them with a site of professional learning at the subject boundaries where they could develop their own ideas and solutions to the various issues posed by integrated teaching and learning, in collaboration with the researchers.

\section{The Structure of the Teaching and Learning Network (TLN)}

The TLN meetings were characterised by mutual engagement and exchange between teachers of different subjects, between teachers and researchers, and between teachers from 
different schools. The structure of the TLN is illustrated in Table 2. Four TLN meetings took place throughout the academic year, with the active research classroom implementation of the unit of learning taking place between TLN 3 and TLN 4. In addition, the researchers visited teachers in their schools to give support in advance of the implementation of the unit. The TLN involved a mixture of researcher direct input on the data-logging technology, inquirybased learning (IBL), and explicit teaching of trend graphs, and teacher input through the design and development of the unit of learning.

Table 2 The Structure of the Teaching and Learning Network (TLN) with a Brief Outline of Activities

\begin{tabular}{|c|c|}
\hline $\begin{array}{l}\text { TLN } \\
\text { Structure }\end{array}$ & Outline of Activities \\
\hline TLN 1 & $\begin{array}{l}\text { Researchers presented the project focus and facilitated training on the data- } \\
\text { logging technology, with a focus on trend graphs. A decision was made by the } \\
\text { teachers involved on the direction of the project for the school year (timeline, } \\
\text { and active research classroom implementation) and there was an agreement on } \\
\text { the model of integration (mathematics within a lower second-level science class). } \\
\text { Teachers were asked to reflect on the project and come up with a topic of } \\
\text { investigation for the next TLN. }\end{array}$ \\
\hline TLN 2 & $\begin{array}{l}\text { The teachers and researchers agreed the topic of investigation - heat and energy } \\
\text { transfer - and began to design the integrated unit of learning. The researchers' } \\
\text { facilitated training on inquiry-based learning (IBL). }\end{array}$ \\
\hline $\begin{array}{l}\text { Integrated } \\
\text { unit of } \\
\text { learning } \\
\text { development }\end{array}$ & $\begin{array}{l}\text { Development of the integrated units of learning by each school (science and } \\
\text { mathematics teacher working together). During this time the researchers visited } \\
\text { the schools to support the use of data-logging technology and the development of } \\
\text { the integrated unit of learning. }\end{array}$ \\
\hline TLN 3 & $\begin{array}{l}\text { Worked on finalising the integrated unit of learning which would be } \\
\text { implemented across all three schools. The researchers facilitated further training } \\
\text { on IBL with a focus on questioning and reflection. TLN } 3 \text { also included further } \\
\text { training and support on the data-logging technology, with a focus on collecting } \\
\text { data using a temperature probe and representing it on a trend graph. }\end{array}$ \\
\hline $\begin{array}{l}\text { Active } \\
\text { research }\end{array}$ & $\begin{array}{l}\text { The implementation of integrated unit of learning in the three schools over a } \\
\text { two-week period. }\end{array}$ \\
\hline TLN 4 & $\begin{array}{l}\text { TLN } 4 \text { reflected on the active research and the implementation of the integrated } \\
\text { unit of learning. }\end{array}$ \\
\hline
\end{tabular}

The teachers led the design of the unit of learning. They identified a topic of investigation, heat and energy transfer, and designed a sequence of science lessons, which specifically focused on the mathematics within this lower secondary science topic. The science topic 
(heat and energy transfer) chosen by the teachers was influenced by the researchers' identification of trend graphs as being one of the most commonly used mathematical practices of representing scientific data in lower secondary science.

The structure of the integrated unit of learning is illustrated in Table 3 below, which was implemented over a two-week period (active research stage).

Table 3 Sequence and Description of the Integrated Unit of Learning

\begin{tabular}{|c|c|}
\hline $\begin{array}{l}\text { Lesson } \\
\text { Number }\end{array}$ & Overview of Lesson Activities \\
\hline $\begin{array}{l}\text { Lesson } 1- \\
\text { single } \\
(35 \mathrm{~min})\end{array}$ & $\begin{array}{l}\text { Introduction to the concept of heat and energy transfer in a lesson designed } \\
\text { to be inquiry based, student-led, task focused. It included examples from real } \\
\text { life that the students could relate to, such as heat transfer in cooking food. } \\
\text { The focus of the lesson was on 'What is radiation? And how can it be } \\
\text { measured? Leading to the class generating ideas on how to test and measure } \\
\text { radiation from different materials. } \\
\text { Mathematics element } \\
\text { Students prompted to plan a data-handling cycle to measure radiation, } \\
\text { identifying variables to be changed and kept constant. }\end{array}$ \\
\hline $\begin{array}{l}\text { Lesson } 2- \\
\text { double } \\
(60 \mathrm{~min})\end{array}$ & $\begin{array}{l}\text { The class investigated the radiation of heat by different materials using } \\
\text { temperature probes, and data-logging technology and the class generated } \\
\text { data from their investigation } \\
\text { Mathematics element } \\
\text { Using the data collected from the temperature probes and data-loggers the } \\
\text { class created trend graphs. Focus on data representation: scale, axes, etc. }\end{array}$ \\
\hline $\begin{array}{l}\text { Lesson } 3 \\
\text { single } \\
\text { (35 min) }\end{array}$ & $\begin{array}{l}\text { The focus of this lesson was on the analysis of the results from the } \\
\text { investigation on the radiation of heat and drawing conclusions from the } \\
\text { findings } \\
\text { Mathematics element } \\
\text { To investigate measures of centrality - why and how they calculated the } \\
\text { average; to examine heat loss; to examine and interpret slope of a trend } \\
\text { graph; to draw conclusions. }\end{array}$ \\
\hline
\end{tabular}

\section{Methodology for Evaluating the Research}

A case study approach was utilised in this research project due to the focus on an empirical study investigating the establishment of a TLN for supporting the integration of mathematics into science teaching and learning in a real world, classroom context (Yin, 
2014). A case study approach is suitable given that it provides an opportunity to construct a detailed representation of the TLN and the integration of mathematics into science, utilising multiple sources of data, experiences and perspectives (see Table 5) (Hamilton \& CorbettWhittier, 2012). Core to a case study approach is the concept of a confined unit which is examined, observed, described and analysed in order to capture key components of the 'case' (Stake, 1995). Loughran (2014) argues that a focus on the CoP as the unit of study frames teacher learning in terms of the social interactions and the community support that he says is crucial to supporting learning and change in practice. Therefore, it is important to note that the TLN is the focus of the case study, rather than each school or individual teachers being a case study in itself. Accordingly, adopting a case study approach provides the researchers with an in-depth insight into the teachers' experiences of the TLN and the supporting role it played in developing their practice (Hamilton \& Corbett-Whittier, 2012).

\section{Participants and Context of the Research}

Three secondary schools and five teachers in the southwest of Ireland participated in this research project. Four of the five teachers had participated in the previous study. Amy was the new member to join the research project due to a retirement by a previous teacher in School C. Within each school the integrated lesson unit was implemented in the science teacher's class with one class grouping of first year students (ages 12 to 13 approximately). Table 4 provides an overview of the participating schools, teachers and numbers of students.

Table 4 Information about Participating Schools and Teachers.

\begin{tabular}{lll}
\hline School \& Teacher & Teacher Subject(s) & $\begin{array}{l}\text { Number of } \\
\text { Participating } \\
\text { Students }\end{array}$ \\
\hline $\begin{array}{l}\text { School } \boldsymbol{A}-\text { Rural Co- } \\
\text { educational } \\
\text { Matthew }\end{array}$ & 27 \\
\hline School B- Urban All-girls & Science and Mathematics \\
\hline
\end{tabular}




\begin{tabular}{lll}
\hline $\begin{array}{l}\text { Norma } \\
\text { Rachel }\end{array}$ & $\begin{array}{l}\text { Mathematics } \\
\text { Science }\end{array}$ \\
\hline $\begin{array}{l}\text { School C-Urban Co- } \\
\text { educational }\end{array}$ & \\
Ann & & \\
Amy & Mathematics & \\
\hline
\end{tabular}

\section{Data Collection}

This study is qualitative in nature and centred on evaluating the establishment of a TLN in supporting teachers to integrate mathematics into science teaching and learning at secondary education. Table 5 provides a list and description of the data collection tools employed in this research project. Utilising multiple sources of data and perspectives allows for triangulation of data and depth of knowledge in relation to the case, and accordingly enhancing findings emerging from the study (Hamilton \& Corbett-Whittier, 2012).

Table 5 Description of Data Collection Tools

\begin{tabular}{ll}
\hline Data Collection Tool & Description \\
\hline $\begin{array}{l}\text { TLN meetings } \\
\text { observation notes }\end{array}$ & $\begin{array}{l}\text { Observation notes were recorded by the researchers for each of the } \\
\text { TLN meetings in order to document key processes and decision } \\
\text { making that took place. }\end{array}$ \\
\hline $\begin{array}{l}\text { Observation of } \\
\text { lessons }\end{array}$ & $\begin{array}{l}\text { The double science lesson (lesson 2) was observed in each of the } \\
\text { three schools. Two observers were utilised - one was a specialist in } \\
\text { science education, the other in mathematics education. The } \\
\text { observers were independent of the research project and were } \\
\text { provided with an observation guide to record notes. The purpose } \\
\text { was to evaluate the participants' integration of mathematics into } \\
\text { their science lessons. }\end{array}$ \\
\hline $\begin{array}{l}\text { Individual teacher } \\
\text { and focus group } \\
\text { interviews }\end{array}$ & $\begin{array}{l}\text { Matthew, Rachel and Amy took part in individual interviews and all } \\
\text { five teachers took part in a focus group discussion with the } \\
\text { researchers, including the authors and four others from the research } \\
\text { centre. The purpose was to elicit teachers' experiences and views of } \\
\text { the experience, and to pool all participants' learnings from the TLN. }\end{array}$ \\
\hline
\end{tabular}




\section{Data Analysis}

A key starting point in the data analysis was returning to the specific research question and identifying the key purposes of undertaking the case study (Hamilton \& Corbett-Whittier, 2012). The authors identified three key purposes in relation to establishing the TLN, namely:

1. Ownership - the TLN was structured and organised so as to provide teachers with an opportunity to collaborate and cooperate on developing their skills and knowledge in relation to integrating mathematics into their science teaching. Year 1 outcomes indicated that a lack of ownership of the design process impacted on their ability to integrate mathematics and science teaching and learning

2. Implementation of integration of mathematics into science-Year 1 outcomes identified challenges teachers had with integrating mathematics and science into their teaching practice.

3. Supporting teachers' professional knowledge development - Year 1 outcomes indicated the need to support teachers in developing professional knowledge in relation to technology, inquiry based learning and mathematical knowledge.

The data was transcribed and organised for data analysis and it was examined in relation to the above themes, exploring the commonalities and differences which emerged (Miles \& Huberman, 1994). In order to ensure reliability, each researcher conducted their own analysis of the data initially and then discussed this analysis in light of findings emerging from the other researchers involved in the project (Bassey, 1999). A further iteration of the analysis was undertaken, with a focus on verifying the validity of the findings (Hamilton \& CorbettWhittier, 2012). The case is reported as a whole, drawing on examples and extracts from individuals within project (Hamilton \& Corbett-Whittier, 2012). 


\section{Findings}

\section{Ownership}

The TLN meetings provided the teachers with an opportunity to participate in a learning community outside of the normal school setting, and with science and mathematics teachers from other schools. A key aim of the TLN was that the teachers would take more ownership of the decision-making process in the design and develop the integrated unit of learning and in the implementation of the unit of lesson during the active research phase. During TLN 1, 2 and 3 the teachers embraced the idea of coming up with the focus of the integrated topic as a group, and they quickly decided upon the topic of heat radiation. The teachers needed little support during the design and planning of the unit of learning and there was a real sense of collaboration, negotiation and consensus-building (TLN 2, observer notes). The teachers made all decisions about the number of lessons, length of lessons, type of investigation, types of materials that would be used in the investigation. They also spoke specifically about trigger questions that they would ask the students when introducing the concept heat radiation, such as 'how do sausages get cooked under the grill? How would you show that objects radiated heat differently? How can we test it?' (TLN 2, observer notes).

One of the findings from Year 1 of this study was that a lack of mathematical knowledge by science teachers impacted on achieving the full potential of the implementation of the integrated unit of learning. Accordingly, a key focus of Year 2 was on supporting the science teachers to make mathematics explicit in the science classroom, with the support and collaboration of the mathematics teachers, both in the TLN meetings and within their schools. In the first two TLN meetings, the researchers re-familiarised the teachers with the use of the data loggers and graphical calculators, introducing them to some new features and to activities relating to statistics that they had not explored in Year 1. This mainly entailed collection of data and its representation on a trend graph, identified by the researchers and 
teachers as a central mathematical practice in science, and which was also a new emphasis in the mathematics curriculum.

Having chosen the science topic of radiation of heat as the focus of the lesson unit, the teachers led a more in-depth discussion of the specifics of the mathematics component, during the detailed lesson unit design session in TLN 3. The teachers identified some possible issues around the investigation such as language, variables, constants, light sources. While these would mainly be incorporated into the third lesson, they planned to allude to them in the second lesson as appropriate also. The teachers discussed the importance of taking more than one measurement during the investigation and how they would encourage the students to take the average of measurements. They identified the links to the mathematics curriculum. The mathematical topics they identified for inclusion in the lesson unit were the concept of slope, meaning of direction of the line on a graph, the concept of average and improving accuracy.

Hence at the level of design of the unit, the teachers, in collaboration with each other and with the researchers, took clear ownership of the integration of mathematics into teaching and learning of the chosen science topic within the lesson unit. The teachers felt that they had adequately addresses the mathematics within the science in the planning of the unit of learning with Matthew stating, 'particularly the third lesson, looking at average, it was more maths based' (Matthew, individual interview).

Importantly there was clear consensus that working in the TLN had been both enjoyable and beneficial, with Amy stating that 'it was brilliant to hear other people's ideas and you know very good ideas were put forward and you kind of think...that would really work and it sort of edges you on a little bit to come up with other different ideas' (Individual interview). Matthew supported this view stating that 'I found that, that was a big plus from last year because we were all kind of singing from the same hymn sheet...I thought that was 
very good as opposed to doing it ourselves' (Individual interview). Similarly, Rachel reported that: 'these are people who know what's happening on the ground, the approach how to use it, the methodology that could be used etc. So there was always good formal and informal transfer of ideas' (Individual interview). As Amy's comment indicates, the group dynamic supported the teachers to creatively cross the boundary between science and mathematics, exploiting the expertise of the group to help them explore the liminal zone between these subjects.

\section{Supporting the Implementation of Integration of Mathematics into Science}

A core focus of establishing the TLN was to support the teachers' integration of mathematics into their science lessons. Two of the three science teachers incorporated the mathematics within the observed science lesson to an extent. Matthew's observed lesson was noted for reinforcing ideas that were being studied in the mathematics classroom and for making sure that 'students understood mathematical terms and gave them real life examples which were very good' during his science lesson (School A, observation). The design of the integrated unit was such that that majority of the mathematics was naturally incorporated in lesson 3 of the unit of learning, with the intention that mathematical aspects would be alluded to as relevant during the course of data collection in lesson 2 (the lesson observed in each case). However, even this less elaborate level of integration of mathematics did not always emerge when lesson 2 was being implemented. The primary focus of Amy's observed lesson 2 was to collect the data, as expected, but with 'no questioning or discussion' taking place in relation to the mathematics component of the lesson (School C, observation). Nonetheless, she did keep emphasising to the students that 'we will analyse this information next Tuesday'. This suggests that she was indeed aware of the importance of the mathematics component, but time constraints were hindering greater exploration of the concepts (School $\mathrm{C}$, observation). From her interview it is very apparent that she has a great appreciation for 
the role of mathematics in science, but 'the problem is we never really point it out to the students' (Amy, individual interview). Both Matthew and Amy felt confident teaching the mathematics component of science and recognised the importance of making the mathematics component explicit for their students' learning from participating in the TLN, 'it was quite useful from the point of view they did start to realise that there are links between [mathematics and] science and between other subjects' (Amy, individual interview).

However, for Rachel, the same outcomes were not observed. From her interview and from her class observation it was apparent that for her, 'maths is always a challenge in science' (Individual interview). As noted by the observer, there was 'no reference to mathematics whatsoever in the class. The teacher once mentioned the word "graph" but other than that mathematics was not a feature in this class' (School B, observation). She very much treated the subjects as separate, 'the science part was great. The maths part I found that you were asking questions on the results part and for them they had no idea beforehand' (Individual interview). Rachel perhaps lacked an appreciation of her role in making the mathematics element explicit for her learners.

On the other hand, Rachel explained that with a very large class of 29 students to manage, with 'mixed ability classes, different prior knowledge, some with good understanding of graphs, others with poor understanding. That would be a challenge anyway' (Individual interview). Rachel was quite clear nonetheless that the lesson unit was of value to the students:

The integration, they loved it, they loved the technology, they loved something new, they loved the fact that they could see the graph being drawn for them. Especially for those who could not draw a graph, who find that part of the maths quite hard. They were having success. (Individual interview) 
In this sense it is not possible to conclude that Rachel's integration of the mathematics was entirely unsuccessful from the observation of a single lesson, as she was very clear about the benefits of the experience to her students.

So, overall for two of the three science teachers, participation in the TLN supported their implementation of the integration unit, to a good degree, and in all cases it enhanced the teachers' awareness of the value of and need to make mathematics explicit in science lessons.

\section{Supporting Teachers’ Professional Knowledge Development}

A key element of the TLN was to provide opportunities for developing teachers' competencies in the use of the technology, as well as developing their knowledge of IBL and mathematics, in order to support the integration of both subject areas within science lessons. Observations of the TLN meetings suggest that by establishing such a community of practice, it afforded them an opportunity to discuss and develop their knowledge of pedagogical opportunities afforded by integrating technology into their lessons. For example, their choice of lesson topic was very much guided by how they felt they could use the specific technology to support the teaching and learning of the mathematics and science content, through an IBL approach (TLN 2, observer notes). Amy said: 'Yes, it was really handy to come in [to the research centre where the TLN meeting were held] and I had [the researchers] at some stage or another sitting beside me and showing me how to do things... I was lucky as I had my cooperating teacher, [Ann] who had worked with it last year so it was really useful to have there was two people in the classroom, when we were showing the students how to use them' (Amy, Interview). This indicates the scaffolding aspect of the TLN in effecting change in Amy's professional knowledge development.

All three teachers demonstrated competence in utilising the technology themselves in the classroom, as well as helping their students to acquire the skills, with the lesson observers noting that overall the students were active in collecting data and once guided by the teacher, 
well able to use the technology. Matthew was particularly adept in integrating the technology effectively to help support and make explicit key mathematical concepts. For example, he was observed asking the students how they would represent the data and displayed a trend graph on the computer and asked students to name the graph (School A, observation).

Similarly, Matthew, Rachel and Amy, in their individual interviews conveyed how supportive the TLN was in developing their knowledge of IBL and the importance of sharing points of view and ideas about how best to incorporate it into their lessons. As emphasised by Matthew (Individual interview), 'Sitting in a group you have several different approaches to trying to teach an IBL lesson, so I found it good' and Amy (Individual interview) reiterated that 'you are always going to have people with useful ideas'. The teachers felt that the TLN helped them to develop their understanding of the concept of an IBL lesson, 'it's a new concept to get across to teachers so it is nice to know where we were all coming from and what we were expected to do or how we go about doing it' (Matthew, individual interview). Observation notes from the double science lessons reveal that there was a good focus on IBL through the use of questioning, but they were teacher-led in many sections and there was an over-use of lower-order and recall question types. For example, in Amy's lesson, the observer noted that there was a focus on the procedure of collecting data with no emphasis on facilitating student understanding of the concepts involved (School C, observation). It is evident that the TLN was useful in helping the teachers to plan an IBL lesson, and develop their understanding of IBL, but there is further support required in relation to modelling implementation in the classroom.

Likewise, the data suggests that involvement in the TLN supported the teachers in developing their knowledge of the mathematics required for this science topic (see previous section). During the final TLN meeting, the teachers shared some of their learnings from the process and revealed their developing expertise as enactors of integrated curriculum. They 
had become more aware of the problems with incorporating integrated teaching into their practice: 'if we knew when our maths teachers were doing trend graphs... being out of sync with what you were normally doing...some people hadn't touched heat or radiation...' (Rachel, TLN 4, focus group). Amy stated that 'unfortunately the topic we had which was heat, normally in most schools that would be done in first year but the way our school had it structured and the plan I was following was that it was done in second year, so my students were at a little bit of a disadvantage' (Amy, individual interview). Matthew reported that 'positive and negative slopes discussion with first years may have been a bit much' (Matthew, individual interview). They had encountered unexpected issues around running out of time in the lessons, students' lack of prior knowledge of either the mathematics or the science, and not getting everything they had planned discussed with the class, but view these as learning opportunities: 'They are just things you learn in the class. The next time I do it I will give them all one colour each and let them read the colour, tell me what [they] got' (Rachel, focus group).

A teacher researcher who participated in the focus group raised the need for greater in-school collaboration: 'If students could link up the science and maths...I find myself saying all the time, what have ye done in maths? Have ye done this or that? And they haven't. So if you could get the science and the maths department together, rather than being two separate departments' (Focus group). The teachers had a detailed discussion of the sequence of mathematics needed to teach graphing in the course of the final focus group. A researcher observer noted: 'You have developed a group identity and a level of expertise in this particular subject which is quite gratifying. A very valuable thing to have built up. You're our experts, our practical experts' (Focus group). 


\section{Discussion}

Findings from this study reveal that the TLN supported teachers to take ownership of the design of the integration, enhance their knowledge and the value they give to integration and to an extent, helped them to begin to change their practice.

In this, the second year of this study, teachers were very actively and enthusiastically involved, in collaboration with the researchers, in the unit design in particular, and as the data shows quite clearly made it their own. Within the TLN, they spent considerable time discussing the pros and cons of various science topics, of how a given topic would work with the data loggers, how an inquiry-based approach could be incorporated, and the mathematics relevant to the science. Within the TLN, and in separate discussions with their cooperating teacher in the schools, the teachers cooperated really well together, and demonstrated a growing common understanding of the issues involved in integrating mathematics into science. Teachers who have collaborated in designing integrated curricular units have shown a shared sense of purpose, growth in knowledge through discussion and sharing of ideas and confidence and eagerness to include integration in their teaching practice (Frykholm \& Glasson, 2005), nurturing and supporting each other through discussion, debate and sharing of ideas (Butler et al., 2004). It gives the two subjects teachers who are co-planning units an opportunity to ensure they use common language and methods between the subjects (Lee et al., 2013).

Research has established that the integration of mathematics and science teaching and learning is beneficial for student learning (Burghardt et al., 2015), yet difficulties arise for teachers in terms of implementing it in their classrooms. These include a lack of time and resources, examinations-focus and negative perceptions (Czerniak \& Johnson, 2014; den Braber, Krüger, Mazereeuw \& Kuiper, 2019). Loughran (2014) emphasises that teacher improvement is centred on their learning, and that this is more effective through collaborative 
initiatives. In this respect the teachers' collaboration through the TLN had a less obvious positive impact on their teaching practice, with respect specifically to the integration of mathematics into the science lesson. While Michael's lesson observation illustrated that he did a very good job of linking the mathematical concepts with the science investigation, the other two teachers were more caught up in the press of getting the students through the process of data collection. Perhaps this change in practice came more quickly to Michael as he is both a science and mathematics teacher, whereas Amy and Rachel are science-only teachers. However, in interview and in the focus group, they too demonstrate a clear appreciation for the importance of mathematics in science and for the need to integrate it into their science teaching. This change in attitude towards integration is an essential precursor to long term change in practice (Authors, 2017). It is also notable that Rachel was teaching students in an urban area, with a greater level of socio-economic disadvantage compared to the other two schools, and whose students, as she alluded to, may have less scientific and mathematical capital (Archer, Dawson, DeWitt, Seakins, \& Wong, 2015). This indicates the importance of supporting such students to increase their STEM capital, and not assuming that one-size-fits-all when it comes to implementing and designing integrated lessons. Further research is required to investigate the impact of socio-economic factors on student achievement in integrated settings.

On the other hand, a change in practice was more evident with respect to the teachers' implementation of inquiry-focused pedagogy, and particularly with respect to the teachers' use of the data-logging technology. In fact, both their technological content knowledge (TK) and their technological pedagogical content knowledge (TPACK) improved considerably since Year 1 (Authors, 2016). This group expertise was readily conveyed to Amy, who had not used the data loggers previously. Given the extent and number of very different innovations that the teachers were attempting to implement in three lessons, it is remarkable 
how very well they did. This can be attributed to the encouragement that participation in the community of practice gave them to experiment with their pedagogy (Putnam \& Borko, 2000).

In this study the teachers' discussions centred on the science first and the mathematics came afterwards. This may be an inevitable outcome of the decision to make mathematics explicit in the science lessons so that the science therefore dictated the mathematics to be integrated (Gresnigt et al., 2014). This is a potential limitation of this approach to integration, but possibly inevitable. Certainly, there was a need for a clear need for more explicit integration of mathematics across all the science lessons in this study, as opposed to specific lessons being dedicated to the 'mathematics' component of science at the end of the unit of learning. In addition, although the science teachers had the support of the mathematics teachers and the researchers within the TLN, there was limited opportunity for them to gain more a more in-depth understanding of the conceptual and curricular connections between science and mathematics (Shulman \& Sherin, 2004). In order to gain a deeper understanding, they would require integrated curriculum materials designed for this very purpose. These are rarely available to teachers (Czerniak \& Johnson, 2014).

Often teacher education programmes do not provide teachers with experiences of, and opportunities for, integration (Berlin \& White, 2012; Furner \& Kumar, 2007). Nor do they usually support them in developing their knowledge of the other subject(s) in order that they can integrate both subjects fully (Stinson et al., 2009). Yet, this research has validated that incorporating such experiences in professional development opportunities can facilitate the development of a greater comprehension of how best to integrate the disciplines (Baxter et al., 2014). Collaboration with teachers of other subjects and other expertise, can help to overcome shortcomings in individual teacher knowledge of particular subjects and pedagogical approaches (Rennie et al., 2012). The literature suggests that communities of 
practice can provide a safe environment for teachers to verbalise and share their learning processes and internal struggles, collaborate and implement change, albeit requiring trust and strong personal relationships (Akerson et al., 2009). Ultimately such participation in CoPs can enhance teacher self-efficacy and lead to better implementation of new methods (Akerson et al., 2009; Lakshmanan et al., 2011) which was the aim in this study too. Successful implementation of integration of mathematics into science was not, however, fully realised in this study. The implication is not that the professional learning community in this case was entirely unsuccessful; rather that the many challenges of integration of mathematics into science were sharpened and came into greater focus in this iteration of the study.

In addition, the study underlined the obvious importance of liaison between science and mathematics teachers with their colleagues within their own schools in order to successfully implement integrated teaching and learning (Shulman \& Sherin, 2004). This was always recognised within this study with the inclusion of the two subject teachers from each school within the TLN. However, it became clear from this study that integration must also take place at the level of organisation of curriculum within the school, if it is to occur at the level of the classroom. Teachers on their own cannot bring about change to the extent required for integration of two subjects, which are planned by separate departments that typically operate in a very insular discipline-focused way (Gleeson, 2010). Hence, while the findings here indicate that the teachers appeared to poorly implement the integrated lessons that they themselves designed collaboratively within the TLN, this occurred in the face of obstacles that are outside the control of the individually well-disposed teacher. Significantly, the teachers themselves articulated their growing recognition of organisational barriers to integration such as the mistiming of when their students are taught the mathematics that they were attempting to incorporate into their science teaching. Ultimately what is required is both school and teacher leadership. This is explained by Rennie et al. (2012) as teacher 
commitment and enthusiasm, with teachers sharing responsibility to promote integrated teaching and learning within a given school context.

The moments of reflection and perspective-taking described above signify that participation in the TLN process has led to professional learning at the boundaries of school science and mathematics for the teachers involved, even where change in practice was not immediately evident. Akkerman and Bakker (2011) discern four mechanisms of learning at the boundaries of professional practice, which they term identification, reflection, coordination, and transformation. They argue that identification and reflection are likely to be conditional for coordination of activities and transformation of practice to occur, because 'boundaries need to be encountered and contested before being put to use for co-developing practices' (Akkerman and Bakker 2011a, p. 151). Successful boundary crossing is not a single act; engaging with the boundary object, reflecting upon it, entering into boundary discourse, and making meaning of it, does not lead automatically to transformation in practice, but if this does not occur, transformation of practice is unlikely to occur.

Most notably, many participants indicated small changes of perspective whereby they began to reconceptualise their attitudes and understandings of their practice because of their participation in the TLN, as indicated by their reflections on the process in the focus group and interviews. The TLN provided the opportunity for communication and collaboration to occur, for participants to develop their ideas, perspectives and potentially expand their subject identities. This is not a small change in the face of the many systemic and organisational barriers to integration, as outlined previously, that teachers face. 


\section{Conclusion}

The authors believe that the TLN model of support of teachers taking risks in mathematics and science integration is needed especially in a time of educational change, in particular the major national curricular changes and developments that are occurring in Ireland. Overall the integration of both subjects could be improved; there is a need for specific mathematics input and more depth in relation to the topics suitable for integration. One major outcome of this current study was subsequent research into developing a curricular model for supporting integration. This focused on how the mathematics and science curricula are connected and how best to organise the curriculum at a school level, as well as providing teachers with exemplary lesson materials (Authors, 2017). Research to investigate if this would further enhance teacher capacity to design and implement integrated learning, within the context of a TLN, would significantly contribute to the literature in this area.

The new lower secondary curricula in Ireland (DES, 2015), with its much less rigid approach to curriculum content, makes the work of connecting the two subjects more feasible than before. This has opened up a curricular space for teachers to make connections across these two closely related subjects. Even so, teachers need a lot of support if they are to take ownership of the integration process. As this study has shown, this can be done through supporting teachers to effect change via the boundary crossing mechanism of the TLN, where science and mathematics teachers and researcher-educators come together to discuss, plan and resolve the inevitable issues that will arise around STEM integration.

\section{References}

Akerson, V. L., Cullen, T. A., \& Hanson, D. L. (2009). Fostering a community of practice through a professional development program to improve elementary teachers' views of nature of science and teaching practice. Journal of research in Science Teaching, 46(10), 1090-1113. 
Akkerman, S. F., \& Bakker, A. (2011). Boundary crossing and boundary objects. Review of Educational Research, 81(2), 132-169.

Authors. (2016). International Journal of Mathematical Education in Science and Technology

Authors. (2017). Chapter in book published by Springer.

Archer, L., Dawson, E., DeWitt, J., Seakins, A., \& Wong, B. (2015). "Science capital": A conceptual, methodological, and empirical argument for extending bourdieusian notions of capital beyond the arts. Journal of Research in Science Teaching, 52(7), 922-948.

Bassey, M. (1999). Case study research in educational settings. Buckingham: Open University Press.

Baxter, J. A., Ruzicka, A., Beghetto, R. A., \& Livelybrooks, D. (2014). Professional development strategically connecting mathematics and science: The impact on teachers' confidence and practice. School Science and Mathematics, 114(3), 102-113. Retrieved from http://dx.doi.org/10.1111/ssm.12060. doi:10.1111/ssm.12060

Berry, A., Loughran, J., Smith, K., \& Lindsay, S. (2009). Capturing and enhancing science teachers' professional knowledge. Research in Science Education, 39(4), 575-594.

Berlin, D. F., \& Lee, H. (2005). Integrating science and mathematics education: Historical analysis. School Science and Mathematics, 105(1), 15-24. Retrieved from http://dx.doi.org/10.1111/j.1949-8594.2005.tb18032.x. doi:10.1111/j.19498594.2005.tb18032.x

Berlin, D. F., \& White, A. L. (2012). A longitudinal look at attitudes and perceptions related to the integration of mathematics, science, and technology education. School Science and Mathematics, 112(1), 20-30. Retrieved from http://dx.doi.org/10.1111/j.19498594.2011.00111.x. doi:10.1111/j.1949-8594.2011.00111.x

Borko, H., Mayfield, V., Marion, S., Flexer, R., \& Cumbo, K. (1997). Teachers' developing ideas and practices about mathematics performance assessment: Successes, stumbling blocks, and implications for professional development. Teaching and Teacher Education, 13(3), 259-278.

Burghardt, M. D., Lauckhardt, J., Kennedy, M., Hecht, D., \& McHugh, L. (2015). The Effects of a Mathematics Infusion Curriculum on Middle School Student Mathematics Achievement. School Science and Mathematics, 115(5), 204-215. Retrieved from http://dx.doi.org/10.1111/ssm.12123. doi:10.1111/ssm.12123

Butler, D. L., Lauscher, H. N., Jarvis-Selinger, S., \& Beckingham, B. (2004). Collaboration and self-regulation in teachers' professional development. Teaching and Teacher Education, 20(5), 435-455.

Czerniak, C. M., \& Johnson, C. C. (2014). Interdisciplinary Science Teaching. In S. K. Abell \& N. G. Lederman (Eds.), Handbook of research on science education (2nd ed., pp. 395-411). London and New York: Routledge.

den Braber N., Krüger J., Mazereeuw M., \& Kuiper W. (2019). Mathematics in an Interdisciplinary STEM Course (NLT) in The Netherlands. In: Doig B., Williams J., Swanson D., Borromeo Ferri R., Drake P. (Eds.) Interdisciplinary Mathematics Education (pp. 167-183). ICME-13 Monographs. Springer, Cham.

DES. (2015). Framework for junior cycle. Dublin Retrieved from https://www.education.ie/en/Publications/Policy-Reports/Framework-for-JuniorCycle-2015.pdf

Dori, Y. J., \& Herscovitz, O. (2005). Case-based long-term professional development of science teachers. International Journal of Science Education, 27(12), 1413-1446.

Frykholm, J., \& Glasson, G. (2005). Connecting science and mathematics instruction: Pedagogical context knowledge for teachers. School Science and Mathematics, 
105(3), 127-141. Retrieved from http://dx.doi.org/10.1111/j.19498594.2005.tb18047.x. doi:10.1111/j.1949-8594.2005.tb18047.x

Furner, J. M., \& Kumar, D. (2007). The mathematics and science integration argument: A stand for teacher education. Eurasia Journal of Mathematics, Science \& Technology Education, 3(3), 185-189.

Gleeson, J. (2010). Curriculum in context: Partnership, power and praxis in Ireland. Oxford: Peter Lang.

Gresnigt, R., Taconis, R., van Keulen, H., Gravemeijer, K., \& Baartman, L. (2014). Promoting science and technology in primary education: a review of integrated curricula. Studies in Science Education, 50(1), 47-84. Retrieved from http://dx.doi.org/10.1080/03057267.2013.877694. doi:10.1080/03057267.2013.877694

Hamilton, L., \& Corbett-Whittier, C. (2012). Using case study in education research. London: Sage.

Hargreaves, A., Earl, L., Moore, S., \& Manning, S. (2001). Learning to change: Teaching beyond subjects and standards. San Francisco, CA: Jossey-Bass.

Hargreaves, A., Lieberman, A., Fullan, M., \& Hopkins, D. (2010). Introduction: Ten Years of Change. In A. Hargreaves, A. Lieberman, M. Fullan, \& D. Hopkins (Eds.), Second international handbook of educational change (pp. xi-xxi). Dordrecht: Springer.

Hobbs, L. (2013). Teaching 'out-of-field' as a boundary-crossing event: factors shaping teacher identity. International Journal of Science and Mathematics Education, 11(2), 271-297.

Howes, A., Kaneva, D., Swanson, D., \& Williams, J. (2013). Re-envisioning STEM education: curriculum, assessment and integrated, interdisciplinary studies, A report for the Royal Society(pp. 1-55). Retrieved from

https://royalsociety.org/ /media/education/policy/vision/reports/ev-2-vision-researchreport-20140624.pdf

Kent, P., Noss, R., Guile, D., Hoyles, C., Bakker, A. (2007). Characterizing the use of mathematical knowledge in boundary-crossing situations at work. Mind, Culture, and Activity, 14(1-2), 64-82.

Lakshmanan, A., Heath, B. P., Perlmutter, A., \& Elder, M. (2011). The impact of science content and professional learning communities on science teaching efficacy and standards-based instruction. Journal of research in science teaching, 48(5), 534-551.

Lave, J., \& Wenger, E. (1991). Situated learning: Legitimate peripheral participation. Cambridge and New York: Cambridge University Press.

Lee, M. M., Chauvot, J. B., Vowell, J., Culpepper, S. M., \& Plankis, B. J. (2013). Stepping into iSMART: Understanding science-mathematics integration for middle school science and mathematics teachers. School Science and Mathematics, 113(4), 159-169. Retrieved from http://dx.doi.org/10.1111/ssm.12015. doi:10.1111/ssm.12015

Loughran, J., Smith, K., \& Berry, A. (2011). Scientific literacy under the microscope: A whole school approach to science teaching and learning (Vol. 11): Springer Science \& Business Media.

Loughran, J. J. (2014). Developing Understandings of Practice. In S. K. Abell \& N. G. Lederman (Eds.), Handbook of research on science education (2nd ed., pp. 811-829). London and New York: Routledge.

Miles, M. B., \& Huberman, M. A. (1994). Qualitative data analysis: An expanded sourcebook (2nd ed.). London and New Delhli: Sage Publications.

Nicolini, D., Mengis, J., Swan, J. (2012). Understanding the role of objects in crossdisciplinary collaboration. Organization Science, 23(3), 612-629. 
NCCA. (2019). Framework for junior cycle. Retrieved from https://www.ncca.ie/en/juniorcycle/framework-for-junior-cycle

NGSS Lead States. (2013). Next Generation Science Standards: For states, by states. Retrieved from http://www.nextgenscience.org/next-generation-science-standards

Offer, J., \& Vasquez-Mireles, S. (2009). Mix it up: Teachers' beliefs on mixing mathematics and science. School Science and Mathematics, 109(3), 146-152. Retrieved from http://dx.doi.org/10.1111/j.1949-8594.2009.tb17950.x. doi:10.1111/j.19498594.2009.tb17950.x

Putnam, R. T., \& Borko, H. (2000). What do new views of knowledge and thinking have to say about research on teacher learning? Educational researcher, 29(1), 4-15.

Rennie, L., Venville, G., \& Wallace, J. (2012). Integrating science, technology, engineering, and mathematics: Issues, reflections, and ways forward. New York and London: Routledge.

Roseno, A. T., Carraway-Stage, V. G., Hoerdeman, C., Díaz, S. R., Geist, E., \& Duffrin, M. W. (2015). Applying Mathematical Concepts with Hands-On, Food-Based Science Curriculum. School Science and Mathematics, 115(1), 14-21.

Shulman, L. S., \& Sherin, M. G. (2004). Fostering communities of teachers as learners: disciplinary perspectives. Journal of Curriculum Studies, 36(2), 135-140. doi:10.1080/0022027032000135049

Stake, R. E. (1995). The art of case study research. London: Sage.

Stinson, K., Harkness, S. S., Meyer, H., \& Stallworth, J. (2009). Mathematics and science integration: Models and characterizations. School Science and Mathematics, 109(3), 153-161. Retrieved from http://dx.doi.org/10.1111/j.1949-8594.2009.tb17951.x. doi:10.1111/j.1949-8594.2009.tb17951.x

Venville, G., Sheffield, R., Rennie, L. J., \& Wallace, J. (2008). The writing on the wall: Classroom context, curriculum implementation, and student learning in integrated, community-based science projects. Journal of Research in Science Teaching, 45(8), 857-880. Retrieved from http://dx.doi.org/10.1002/tea.20245. doi:10.1002/tea.20245

Yin, R. K. (2014). Case study research: Design and methods (5th ed.). Thousand Oaks, CA: Sage. 